\title{
The multiple identities of sustainability
}

\begin{abstract}
.
Sustainability is one of the most complex composite constructs to have emerged in the last decade. Having a clear understanding of its meanings is critical as actions based on these understandings impact all walks of life. We track the conceptualizations and measurements of sustainable development in the areas of government, business, education, and the trades. We explore what stakeholders in these groups value in sustainability by observing where they develop initiatives, invest funds, and report progress. What emerges is a picture of diversity in how stakeholders view sustainable development, one of multiple identities, driven by distinct logics and motives. Based on these findings, we propose that, instead of reconciling these diverse perspectives, we might focus on constructing shared understandings around critical values.
\end{abstract}




\section{Introduction}

Despite significant efforts, a clear definition of sustainability continues to elude us. While the use of the word has increased to the point of becoming a buzzword, it's meaning has flattened and has become synonymous with anything that is either good or neutral (Károly, 2013). Attempts to understand what sustainability means and to integrate it in our lives have been numerous. Of all the conferences held every year, many now have at least some sections dedicated to sustainability topics. Similarly, the number of publications, books, and articles covering various aspects of sustainability has increased tremendously.

Still, an increase in interest and use of this concept has not brought a better understanding of it. Morelli (2013) explains that the concept has been transformed from scientifically definable to a notion open to interpretation by anyone. As a result, individuals and organizations struggle to define it. Károly goes even further by stating that "the expression has been inflated, overused, misused, and abused" (2013:1). In some cases, such as the issue of climate change, the concept has become a cultural artifact susceptible to belief instead of proof (Hoffman, 2010). Finally, many organizations consider this a powerful fad that should be employed for reputational benefits (Tetrault Sirsly \& Lamertz, 2008).

At the same time, however, many organizations in different fields have increased their efforts to operate in a less harmful way towards the environment. We know this because many firms provide reports that highlight sizeable investments in substantive sustainable initiatives. Yet that ideal of a collaborative environment among multiple stakeholders is still elusive (Melhus \& Patton, 2012). We cannot overstate the importance of developing meaning based on a shared understanding of what sustainability means. Undeniably, sustainability has become a global strategic imperative, which lead governments to develop policies, corporations to formulate 
strategies. Also affected are new infrastructure investments, new products and services, practices regarding human resources, and time horizons for future investments. These changes now take into account how each professional group defines sustainability and what is considered pertinent to future opportunities. Still, a poor understanding can lead to confusion, dissent, or dispute among entities that should work towards shared goals.

In this paper, we aim to bridge this gap by comparing how different professional contexts prioritize their sustainability efforts and offering an explanation for the different approaches. The ultimate aim of this paper is to show that the underlying logic, which created these organizational forms, guides their approach to sustainability and that their path dependence is a strong yet rather slow force. While shared meanings of sustainability are critical and not negotiable (Károly, 2013), reaching these shared understandings may take some time. Our finding that most professional contexts include several dimensions of environmental sustainability in their top priorities is promising.

\section{The identity of sustainability}

While the most accepted definitions of sustainability offer accessible dimensions, such as the triple bottom line, the applicable domains of human activity are subject to interpretation. As a result, professions differ in their conceptualization and application of sustainability depending on how they approach the question of what is sustained? A major motive for divergence is found in the different levels of analysis. For example, management thinkers are focused on variables that deal with sustaining organizational systems, sociologists — on individuals or groups, and political scientists — on even broader populations, defined around geopolitical borders. At the same time, it is telling that the environmental movement was initiated in close connection with 
the sciences, specifically, biology, also the study of life. Rachel Carson wrote about the effects of human activity on life in her book Silent Spring (1962). Through this work, a necessary connection is made between the broad and complex planetary level of analysis to the granular, if still very complex, notion of life. Hence, core to the sustainability is the idea of 'life,' understood as a "characteristic that distinguishes objects that have signalling and self-sustaining processes from those that do not", including "capacity for growth, reproduction, functional activity, and continual change preceding death" (American Heritage Dictionary, 2006).

It is a common assumption that successful organizations possess an identity that is known by their primary stakeholders. Common elements of an identity include what it is, what it stands for, a purpose and what may be expected from it. Moreover, national identities can be "a lightning rod, for better or worse" (Strugatch, 1992: 75). We could go as far as to state that whether stakeholders rally behind an organization will largely depend on their understanding of its identity. Hence, we may conclude that it would be more strenuous to gain support if the identity is confusing. This becomes particularly relevant when discussing initiatives and investments made by organizations in the area of sustainability. A poor understanding of sustainability means that organizations may abuse its meaning or become susceptible to intentionally confusing symbolic actions for substantive ones (Tetrault Sirsly \& Lamertz, 2008).

Most understandings of sustainability can be categorized by their reliance of survival and resource dependence as core definitional elements. Survival of a human system is paramount to most conceptualizations, as is the need to preserve critical resources upon which the survival of human systems is dependent. As such, when convergent, most thoughts around sustainability coalesce around the idea that organized human survival should be the priority. Similarly, the survival of natural planetary systems is only relevant to the extent that these systems can support 
human life. This type of thinking has opened loopholes for some to argue that the extinction of a non-critical species should not necessarily be prevented, if the survival of humankind is at stake. Yet the kinds of resources that would require protection are those perceived as critical to inputs into the production processes (Darnall and Edwards, 2006).

Beyond these two primary elements, scholars and practitioners alike rarely converge on how sustainability should be approached. Some point to a lack of uncontested definition (McGee, 1998; Rugman and Verbeke, 1998), while others indicate that there is a lack of cohesiveness (Etzion, 2007). Between disciplines, researchers attempt to find common meaning while applying principles of sustainability to topics ranging from environmental engineering (Glavič and Lukman, 2007), ethics and management (Fergus and Rowney, 2005), education (Bonnett, 1999), international development and poverty reduction (Lélé, 1991; Stapleton and Garrod, 2007), and land economics (Norton and Toman, 1997).

Terminology and semantics are critical to obtaining a shared understanding of sustainability, especially given that more terms are added to the panoply of sustainability every year, along with innovative ways to measure the achievement of the associated goals. Hence, with organizations of all kinds reporting their sustainability performance, we may be shortchanged in our ability to evaluate said performance and attempts by organizations to communicate legitimate work may be misinterpreted as reputation enhancement tactics. Understanding meanings and definitional accuracy should precede the development of measures used for reporting.

If definitions are unclear or confusing, their measurement will lack validity. This is further complicated by the use of index measures. Given the composite nature of sustainable development, scholars and practitioners have developed composite measures to fit the needs of their organizations or fields. While sustainable development does lend itself to the development 
of index measures, it is not uncommon for indices to not account for important elements, such as space and time (Niu et al., 1993), or to account too much for other dimensions, based on a previously developed agenda driven, as in the case of well-being indices (Stapleton and Garrod, 2007). Finally, the issue is further complicated by the increasing use of online media by organizations, in their attempt to communicate and persuade the general public of their sustainability efforts (Isenmann et al., 2007).

We see sustainability as an integrative construct, such that it brings together notions from several disciplines and fields of study. To some extent, we may expect that divergent meanings may be brought together under this umbrella. Similarly, we may expect that, at some point, these divergent meanings should be reconciled within theoretical and applicative frameworks. For this to happen, a shared understanding among the different actors involved in defining and applying sustainability principles should develop. Yet, how sustainability principles have evolved and are operationalized has tended to be fragmented and unclear, leaving much room for interpretation (Morelli, 2013), misuse, distortion, and abuse (Károly, 2013), leaving room for an otherwise munificent concept to develop a case of multiple personality disorder.

\section{Methods}

\section{Context.}

To gain a comprehensive appreciation of how organizations conceptualize, measure, and employ sustainable development in their activities, we explore academic, trades, business, and government sectors. The academia has shown an interest in sustainability for many decades, contributing over the years, measurements of socio-environmental impact and theoretical understandings in various disciplines. Presently, universities have embedded sustainable 
development in their research and teaching curriculum. We examine the extent to which sustainability is embedded in the most well known faculties around the globe and in what way. Regarding the trades, we explore the professional conferences held around the globe during a period of a year and code the themes and topics covered under the sustainable development umbrella. In the government sector, sustainable development appears at various levels. We explore the implementation of policies at country level and state level in the U.S. Finally, in the business context, we use sustainability reports of the top Fortune 15 companies. We consider that studying this complex concept in multiple settings is critical to improve our understanding of the multiple meanings, measurements, and implementations. Understanding the motives of various actors is one step forward in trying to untangle what otherwise may appear as a Babylonian misunderstanding.

\section{Sample and measures.}

In a desire to look at multiple perspectives, governments, businesses, academics, and association, sampling techniques varied depending on the target population. When looking at the government perspective, two different levels of government were examined. First were the various approaches to sustainable development used by states within the U.S. The Association of State and Territorial Solid Waste Management Officials (ASTSWMO) publishes a "Greening State Government Page, which is a guide the government programs in the U.S. that was created to identify and document what state government are doing in their own operations.

(www.astswmo.org). The data reported are categorized by relevant Greening State Government implementation resources and which operations or activities were targeted by each state. In assessing the sustainable development of nations, the data collected by the World Economic Forum and published in the Global Competitive Report 201-2013) were analyzed. The WEF's 
model of sustainability consists of two pillars, one is social sustainability and the other is environmental sustainability. Combining the two pillars, produces an overall rating sustainability competitiveness index for 144 countries. We also compiled data from the top 15 universities of the News Report Top 400 universities around the world. Finally, we chose the top 15 companies that appear in the Forbes list of the top corporations. The primary unit of analysis across these samples is the sustainability priority expressed by these entities in a strategic form.

\section{Data and analytical approaches.}

Data regarding sustainability approaches used by universities came from the websites hosted by each institution. Some universities developed websites dedicated to reporting their sustainability efforts and initiatives, while others designed single pages describing activities or defining their vision. Universities have been implementing sustainability in a variety of ways. Some create sustainability centers or institutes, others have a sustainability-themed college or faculty, endowed chairs, majors or programs dedicated to the topic, courses, student organizations, and campus initiatives. Some of these are curriculum-based, others regard student life, while others have an impact on administrative decisions. We coded for all these factors in our sample, using available information on the universities' websites. Regarding sustainability institutes or centers, in most cases centers or institutes are discipline specific: forestry, law, engineering, etc. At some universities, more than one center/institute might exist, representing different disciplinary areas. Regarding student organizations, on some campuses multiple sustainability-themed organizations exist. Finally, campus initiatives are often carried out through a campus Office of Sustainability. Areas of interest can include: green campus, carbon management, construction, refurbishment, procurement, awareness, ethical investment, and transport. 
In examining the ways countries view sustainability, the work of the World Economic Forum was selected as a reliable source of information and data. The Global Competitive Report 20122013 included a chapter on Assessing the Sustainable Competitiveness of Nations. The WEF reviewed various previously identified methods and metrics for capturing the concept of sustainability. After the review, the WEF chose to use an integrated model of environmental and social sustainability metrics. The definition the WEF developed of Environmental Sustainability is "the institutions, policies, and factors that ensure an efficient management of resources to enable prosperity for present and future generations (p. 52)." Their definition of Social Sustainability is "institutions, policies, and factors that enable all members of society to experience the best possible health, participation, and security; and that maximize their potential to contribute to and benefit from the economic prosperity of the country in which they live" (p. 52). Based on the relationships between these two definitions, the WEF developed the following definition of Sustainable Competitiveness. “...the set of institutions, policies, and factors that make a nation remain productive over the longer term while ensuring social and environmental sustainability. A summary of the 18 indicators used in examining the environmental and social sustainability pillars, which were used in the reported sustainability index is provided in the paper. The WEF was able to gather sufficient sustainability data for only 79 of the 144 countries covered in their Global Competitive Index. There is no standard way in which to record or capture information on the indicators, the WEF choose to utilize. The WEF did not find any theoretical guidelines for assigning weights to the various indicators, so each was given equal weight within in pillar. The individual indicators were normalized on a 1-to-7 scale and aggregated by averaging the normalized scores for each country. 
Regarding sustainability priorities in US states, the Association of State and Territorial Solid Waste Management Officials (ASTSWMO) publishes a Greening State Government Page, which is a guide to the government programs in the U.S. created to identify and document what state governments are doing in their own operations (www.astswmo.org). The data reported are categorized by relevant Greening State Government implementation resources and which operations or activities were targeted by each state. The operational definition used by ASTSWMO in their work was: "A formal program designed to minimize (beyond regulatory compliance)the environmental impacts associated with State agency procurement, land use, construction, facility management and operations, and employee commuting or business travel."

Business/Corporate. Our sample included the top 15 corporations from the 2013 Forbes 100. Most of the data used in this paper came from each of the company's most recent sustainability reports. Where available, we consulted their formal reports, or dedicated websites. in instances where sustainability or corporate responsibility information was not directly available from company sources, we looked for data from third parties, such as databases and trade articles about the company. Corporate data used in this study were downloaded between September and October 2013.

To understand the priorities in the trade and professional groups, we retrieved data from the conference aggregator website Conference Alerts (2013), and concentrated on 119 conferences that include sustainability topics in their programs. These conferences span the globe and many different disciplines, indicating that sustainability is on the agenda of many professional groups, and that more and more trades are seeking ways to integrate sustainability in their disciplines. To gain a more in-depth understanding of the various disciplines and topics associated with 
sustainable development, we compiled a list of conference topics along with their frequency, based on the sample of 119 events of 2013.

\section{Results}

\section{World Economic Forum and the sustainability of countries.}

Of the 79 countries for which WEF data were available, the average sustainability index ranged from a low of 2.9 (Pakistan) to a high of 6.85 (Switzerland) on a 7 point scale. The average for all 79 countries was 4.42 . When examining the individual scores for the two pillars, Environmental Sustainability and Social Sustainability, the same two countries ranked first and last.. On social sustainability, Switzerland topped the list with a score of 6.83, while Pakistan received a score of 2.84. On environmental sustainability, Switzerland scored 6.87 and Pakistan scored 2.96. Three countries received equal scores on both social and environmental sustainability, which would indicate an equal weighting of the two pillars. The three countries that had equal scores were Iran (3.85), Moldova (3.75) and the Dominican Republic (3.29). Table 1 below shows a summary of these data.

\section{Table 1. World Economic Forum and sustainability priorities}

\begin{tabular}{ll}
\hline \multicolumn{1}{c}{ Areas of strategic focus in sustainability } \\
\hline \multicolumn{1}{c}{ Environmental Sustainability } & \multicolumn{1}{c}{ Access to basic necessities } \\
\hline Environmental policy & Access to basic necessities \\
- Environmental regulations & - Access to sanitation \\
- Number of ratified treaties & - Access to improved drinking water \\
- Terrestrial biome protecting & - Access to healthcare \\
& \\
Use of renewable resources & Vulnerability to shocks \\
- Agricultural water intensity & - Vulnerable employment \\
- Forest depletion & - Extent of informed economy \\
- Fish stock's overexploitations & - Social safety net protection \\
& \\
Degradation of the environment & Social cohesion \\
- Level of particulate matter & - Income Gini index \\
- CO2 intensity & - Social mobility \\
- Quality of the natural environment & - Youth unemployment \\
\hline \multicolumn{2}{c}{ Source: World Economic Forum }
\end{tabular}


It is interesting to note that the scores of these three countries ranked in the lower half of all countries studied. Of the 76 countries that had differences between environmental and social sustainability, the majority (47 countries) scored higher on social sustainability than on environmental sustainability. The county with the greatest difference between the two pillar scores was Kazakhstan, which scored 4.53 on Social Sustainability and 3.5 on Environmental Sustainability. Twenty-nine countries scored higher on Environmental Sustainability. Of the countries that scored higher on environmental sustainability, Kenya had the greatest differential. It scored 3.76 on environmental sustainability and 3.01 on social sustainability. These findings suggest that more countries are focused on aspects of Social Sustainability than on Environmental Sustainability, which most likely results in a more short-term immediate focus than on the long-term.

Table 2 below shows a comparison between four professional contexts regarding the top priorities of sustainability. 
Table 2. Top ten priorities in sustainability

\begin{tabular}{|c|c|c|c|c|c|c|c|c|}
\hline Rank & $\begin{array}{l}\text { Academic/ } \\
\text { Universities }\end{array}$ & $\%$ & Trades/professions & $\%$ & US States & $\%$ & Forbes 15 companies & $\%$ \\
\hline 1 & Emission reduction & 95 & $\begin{array}{l}\text { Energy (reduction, } \\
\text { renewable, alternative, } \\
\text { clean) }\end{array}$ & 10.3 & Energy & 91 & Employee engagement & 73 \\
\hline 2 & $\begin{array}{l}\text { Energy use and } \\
\text { conservation }\end{array}$ & 90 & $\begin{array}{l}\text { Business (incl. corporate } \\
\text { governance, management, } \\
\text { marketing, } \\
\text { entrepreneurship, } \\
\text { etc.) }\end{array}$ & 7.2 & $\begin{array}{l}\text { Construction / Green } \\
\text { buildings }\end{array}$ & 82 & $\begin{array}{l}\text { Environmental } \\
\text { stewardship (air, water, } \\
\text { land) }\end{array}$ & 73 \\
\hline 3 & Reduce waste & 80 & $\begin{array}{l}\text { Planning (urban, rural, and } \\
\text { regional development) }\end{array}$ & 7.2 & $\begin{array}{l}\text { Procurement/ } \\
\text { Purchasing }\end{array}$ & 80 & $\begin{array}{l}\text { Energy diversity with } \\
\text { focus on renewable } \\
\text { sources }\end{array}$ & 60 \\
\hline 4 & Recycle & 80 & Engineering & 6.3 & Material Management & 76 & $\begin{array}{l}\text { Economic development } \\
\text { in the communities }\end{array}$ & 47 \\
\hline 5 & $\begin{array}{l}\text { Green campus } \\
\text { construction and } \\
\text { operations }\end{array}$ & 80 & $\begin{array}{l}\text { Environment (biodiversity } \\
\text { and related issues) }\end{array}$ & 5.8 & $\begin{array}{l}\text { Facilities management / } \\
\text { Operations }\end{array}$ & 71 & $\begin{array}{l}\text { Corporate governance } \\
\text { and corporate integrity }\end{array}$ & 40 \\
\hline 6 & $\begin{array}{l}\text { Students } \\
\text { engagement } \\
\text { (research, teaching, } \\
\text { service) }\end{array}$ & 75 & Academic / education & 5.3 & State vehicle fleet & 69 & Community volunteerism & 40 \\
\hline 7 & Water use & 70 & $\begin{array}{l}\text { Social responsibility (incl. } \\
\text { bottom of pyramid, } \\
\text { corporate responsibility, } \\
\text { poverty, stakeholder } \\
\text { engagement, women } \\
\text { studies, etc.) }\end{array}$ & 4.9 & $\begin{array}{l}\text { Greenhouse gas } \\
\text { emissions }\end{array}$ & 62 & $\begin{array}{l}\text { Health and safety in the } \\
\text { workplace }\end{array}$ & 33 \\
\hline 8 & Procurement & 70 & $\begin{array}{l}\text { Technology (information } \\
\text { technology, research and } \\
\text { development, etc.) }\end{array}$ & 4.9 & $\begin{array}{l}\text { Commutes, business } \\
\text { travel }\end{array}$ & 60 & $\begin{array}{l}\text { Human rights and } \\
\text { security }\end{array}$ & 27 \\
\hline 9 & $\begin{array}{l}\text { Improve indoor } \\
\text { environment }\end{array}$ & 65 & Water management & 3.6 & $\begin{array}{l}\text { Education (intra-agency, } \\
\text { interagency, external) }\end{array}$ & 58 & $\begin{array}{l}\text { Employee programs and } \\
\text { diversity }\end{array}$ & 27 \\
\hline 10 & $\begin{array}{l}\text { Support community } \\
\text { efforts }\end{array}$ & 60 & $\begin{array}{l}\text { Construction (incl. } \\
\text { architecture, housing, etc.) }\end{array}$ & 3.1 & Air quality & 49 & $\begin{array}{l}\text { Waste management and } \\
\text { recycling }\end{array}$ & 20 \\
\hline
\end{tabular}

\section{Sustainable development in the academic context.}

Our results from the top 20 universities show that there is little variance in how sustainability is implemented. For instance, of the 20 top universities, 18 have established a sustainability center or institute others have created a sustainability college or faculty. Regarding curriculum, there is widespread development of programs and courses on topics related to sustainability. 19 of the top 20 schools have created either a major or a program in this area and nearly all schools in the sample offer courses in the sustainability. Regarding campus life, 17 of the top 20 have at least one student organization on campus active in a sustainability activity and 19 of the top 20 are implementing campus initiatives. We did not distinguish between the quantity or quality of initiatives in this study, therefore it is difficult to rank where some schools do more than others. 
The purpose of this study, however, was not to go into much depth in the types of initiatives developed, but to show whether these types of activities are represented in the academic sample. Note also that among the top five priorities there is significant degree of adoption among the top schools, of at least $80 \%$.

\section{Sustainable development in the trade and professional context.}

The most common area of interest regarding sustainability is in conferences that deal with some aspect of energy use, be it reduction, renewable sourcing, or developing alternative or clean energies. Note also the diversity of conference disciplines, which now include the topic of sustainable development in their programs. On one hand, the inclusion of sustainable development in such diverse contexts is promising news. On the other, what is worrisome in this observation is that practitioners and academics working through their respective associations and events continue to view sustainable development as a concept to be appropriated within the confines of a disciplinary silo. This situation further underscores the importance of achieving a shared understanding of the fundamental meaning and definitional dimensions of sustainable development among the trades, which work on integrating it into their rationales. Not achieving interdisciplinary integration leaves the door open for conflicting understandings of sustainable development in real world applications.

\section{Sustainable development in the government context.}

The ASTSWMO used thirteen classifications of targeted operations or activities: 1) Air Quality, 2) Construction/Green buildings, 3) Education (intra agency, interagency or external), 4) Commutes, business travel, 5) Energy, 6) Facility Management, 7) GHG Emissions, 8) Hazardous Waste, 9) Land use, 10) Procurement, 11) Materials management, 12) State vehicle fleet, and 13) Water Conservation. Table 2 shows the number of states that targeted operations 
and activities in each of the thirteen categories. The most frequently mentioned activities were related to energy. Eighty-two percent of the states indicated that they had some operations or programs related to energy conservation. The second most common activity among the states was in green construction. Seventy-four percent of the states had some activities related to constructing more energy efficient buildings. The categories with the fewest number of activities was land use. Only 15 states reported activities related to sustainable land use. There was substantial variation among the states in the number of activities or operations related to sustainability. Five states reported no activities, while at the other extreme, eight states reported activities in all thirteen categories. States reporting no activities were Alabama, Alaska, Kentucky, Tennessee, and West Virginia. The eight states reporting activities in all thirteen categories were: North Carolina, Oklahoma, Oregon, Vermont, Virginia, Arkansas, Idaho, and Minnesota.

The ASTSWMO data appear to be primarily based more on environmental sustainability than on social sustainability. Of the 12 activities/operations classifications identified the majority are focused on the environment This is not surprising since the purpose of their work as described on thieir website (www.astswmo.org/) is to identify and document examples that "conserve natural resources, achieve energy efficiency, reduce costs and encourage environmentally sustainable behaviors." The ASTSWMO survey asked states to identify how the program was first initiated. Of the 40 states that gave a response to this question, Table --- shows the responses.

\section{Sustainability in the business context.}

To learn about how sustainability is defined in the business context, we looked at the Forbes 15 corporations' social responsibility reports and made note of the areas of strategic focus 
identified and self-reported on. Table 2 shows the top ten areas of strategic focus identified by the largest corporations in the world. A significant majority (73\%) of firms consider employee engagement and environmental stewardship to be key issues to address in the area of sustainability. Employees are often considered as an important creative resource to firms, especially through championship of initiatives than can lead to new products or community programs. Environmental stewardship focuses on the use of resources. Another important area of interest to many firms $(60 \%)$ is the use of energy, specifically focusing on diversifying the sources of energy with a goal of increasing reliance on renewable sources. Almost half of the major corporations include the economic development of communities as part of their conceptualization of sustainable development. Some firms (40\%) achieve community involvement through volunteerism. Good corporate governance practices and integrity are now key areas of strategic interest to almost half of the Forbes 15 firms (40\%). Looking further down the list of priorities, firms value community volunteerism (40\%) and devise programs that incentives and sometimes reward employees for engaging in community actions. Other initiatives include direct community investments in social programs, such as literacy, education, and the like. The focus on employees and workplace is evident as we look at the other categories in the list of priorities of top firms, where firms invest in workplace safety (33\%), security and human rights (27\%), diversity-related programs (27\%), and waste management and recycling $(20 \%)$.

\section{Comparisons.}

In comparing the top priorities among the academic, professional, government, and business fields, some conclusions can be drawn. Understanding that the data represents communicated 
intentions, not factual achievements, the important point must be made that these intentions drive policies and implementation strategies for these major players.

First, note the difference in visions behind these priorities. While they all contain strategic and tactical elements, some are more generic while others are more specific. For instance, the trades will discuss themes around the natural environment and corporations discuss the broad notion of environmental stewardship, while academics will devise very specific initiatives around environmental issues, like water, emissions, and energy use. Or states formulate general ideas around the education of employees and other stakeholders, while universities devise specific outcomes around educational engagement through research, teaching and service.

Second, the issue of participation and agreement within professions is important, as not all have the same level of participation. Note the percentage points next to each of the priorities. These denote the level of agreement within our sample around these issues. For instance, the academic and government professions have much higher participation in the top five priorities than the others. There is less agreement among these themes within the corporate sample, and the trades sample is even more dispersed.

Third, there seems to be some agreement around major themes, such as emissions, energy, transportation, construction, procurement and operations, with all players devising some priorities around these issues. These priorities have a distinctive mark of environmental sustainability instead of social or economic, recognizing the importance of the environment as a strategic priority among these professional contexts. 


\section{Multiple identities: divergence or integration}

There is an abundance of literature showing that the concept of sustainability, upon which theory, policy, and practice are developed, is going through an identity crisis. Long after first being introduced in the sciences, the term has seen transformations, changes and even abuses (Károly, 2013) and is far from offering a clear definition and a shared understanding of its critical dimensions. To attempt a reconciliation of its meanings for practitioners, in this paper we show how different professional settings conceptualize and prioritize sustainability at a strategic level.

The main thrust of this paper has been to understand the underlying logic behind the multiple identities of a pervasive concept. Where it was previously shown that there are significant differences in how institutional actors and the public conceptualize sustainable development (Ratiu and Anderson, 2013), we wish to unpack some of these differences and move the debate beyond the inner semantic conflict. As such, we are less concerned with the descriptive element of identity conflict, and more interested in understanding why it exists. The empirical research undertaken here indicates that sustainability is seen differently by different actors. While there is much in common as far as the core definitional elements, the areas of emphasis are different. At the outset, we suggested that this should be explained by identity, values, and strategies of the professions, which drive organizations to make different choices. As such, we have shown that government, academic, business, professional, and trade organizations view sustainability differently.

These findings recognize the need for professions to develop their own understanding of sustainability and to strategically prioritize the actions to be undertaken. At the same time, we 
agree with Károly (2013) that environmental sustainability is not negotiable. Hence, this work implies that professions should ensure that environmental priorities are among the top when it comes to allocating resources. More specifically, if convergence is sought around key themes, the basics of environmental sustainability should be covered, while at the same time acknowledging that there will be differences among the priorities and level of advancement of different professions.

The primary contribution of this paper is to show why and how sustainable development may be viewed differently by organizations pertaining to different sectors. We identify these differences and explain what may be the cause of these differences. As a result, we contribute to the essential dialogue aiming to define sustainability for theoretical and practical purposes and push the discussion beyond the descriptive identification of divergent worldviews. 


\section{References}

The American Heritage Dictionary, (2006), The American Heritage Dictionary of the English Language, 4th edition, Houghton Mifflin Company.

Bonnett, M. (1999), "Education for sustainable development: A coherent philosophy for environmental education?" Cambridge Journal of Education, Vol. 29 No. 3, pp. 313-324.

Byrch, C., Kearins, K. Milne, M. and Morgan, R. (2007), "Sustainable 'what'? A cognitive approach to understanding sustainable development", Qualitative Research in Accounting and Management, Vol 4, Issue 1, pp. 26-41.

Carson, R. (1962), Silent Spring, Houghton Mifflin.

Conference Alerts. (2013), Conferencealerts.com, retrieved Feb 18, 2013.

Darnall, N. and Edwards, D.J. (2006), "Predicting the cost of environmental management system adoption: The role of capabilities, resources \& ownership structure", Strategic Management Journal, Vol. 27 No. 4, pp. 301-320.

Drago, K. (2012), “Sustainable Development: Implementing Utopia?” Sociologija, Vol. 54, Issue 1, pp. 7-20.

Etzion, D. (2007), "Research on organizations and the natural environment, 1992-present: A review", Journal of Management, Vol. 33 No. 4, pp. 637-664.

Fergus, A.H.T. and Rowney, J.I.A. (2005), "Sustainable development: Lost meaning and opportunity?" Journal of Business Ethics, Vol. 60, pp. 17-27. DOI: 10.1007/s10551-005$2927-9$ 
Glavič, P. and Lukman, R. (2007), "Review of sustainability terms and their definitions”, Journal of Cleaner Production, Vol. 15 No. 18, pp. 1875-1885, DOI: 10.1016/j.jclepro.2006.12.006.

Hoffman, A.J. (2010). Climate change as a cultural and behavioral issue: Addressing barriers and implementing solutions," Organizational Dynamics, 39(4): 295-305.

Isenmann, R., Bey, C. and Welter, M. (2007), “Online reporting for sustainability issues”, Business Strategy and the Environment, Vol. 16 No. 7, pp. 487-501. DOI: 10.1002/bse.597.

Joshi, A., Dencker, J.C., Gentz, F. and Martocchio, J.J. (2010), “Unpacking Generational Identities in Organizations", Academy of Management Review, Vol. 35, No 3, pp. 392-414.

Károly, K. (2013). Rise and fall of the concept sustainability. Journal of Environmental Sustainability, 1(1): 1-12.

Lélé, A.M. (1991), “Sustainable development: A critical review”, World Development, Vol. 19 No. 6, pp. 607-621, DOI: 10.1016/0305-750X(91)90197-P

McGee, J. (1998), “Commentary on corporate strategies and environmental regulation: An organizing framework", by A.M. Rugman and A. Verbeke. Strategic Management Journal, Vol. 19, pp. 377-387.

Melhus, P. \& Paton, B. (2013), The Paradox of Multi-Stakeholder Collaborations: Insights from Sustainable Silicon Valley’s Regional CO2 Emissions Reduction Program. Journal of Environmental Sustainability, 2(2)" 29-44

Morelli, J. (2013), Environmental sustainability: A definition for environmental professionals. Journal of Environmental Sustainability, 1(1):1-9. 
Niu, W.Y., Lu, J.J. and Khan, A.A. (1993), "Spatial systems approach to sustainable development: A conceptual framework", Environmental Management, Vol. 17 No. 2, pp. 179-186.

Norton, B.G. and Toman, M.A. (1997), "Sustainability: Ecological and economic perspectives", Land Economics, Vol. 73 No. 4, pp. 553-568.

Ratiu. C. \& Anderson, B. (2013), The identity crisis of sustainable development. World Association for Sustainable Development, London, UK

Rugman, A.M. and Verbeke, A. (1998), "Corporate strategies and environmental regulations: An organizing framework", Strategic Management Journal, Vol. 19, pp. 363-375.

Stapleton, L.M. and Garrod, G.D. (2007), "Keeping things simple: Why the Human Development Index should not diverge from its equal weights assumption", Social Indicators Research, Vol. 84 No. 2, pp. 179-188.

Strugatch, W. (1992), World Trade, Vol. 5, Issue 6. pp. 74-78.

Tetrault Sirsly, C.A. \& Lamertz, K. (2008). When Does a Corporate Social Responsibility Initiative Provide a First-Mover Advantage? Business \& Society, 47(3), 343-369. 